NBER WORKING PAPER SERIES

THE BACK STORY OF TWENTIETH-CENTURY ART

\author{
David Galenson \\ Working Paper 14066 \\ http://www.nber.org/papers/w14066 \\ NATIONAL BUREAU OF ECONOMIC RESEARCH \\ 1050 Massachusetts Avenue \\ Cambridge, MA 02138 \\ June 2008
}

The views expressed herein are those of the author(s) and do not necessarily reflect the views of the National Bureau of Economic Research.

NBER working papers are circulated for discussion and comment purposes. They have not been peerreviewed or been subject to the review by the NBER Board of Directors that accompanies official NBER publications.

(C) 2008 by David Galenson. All rights reserved. Short sections of text, not to exceed two paragraphs, may be quoted without explicit permission provided that full credit, including $\odot$ notice, is given to the source. 
The Back Story of Twentieth-Century Art

David Galenson

NBER Working Paper No. 14066

June 2008

JEL No. J01

\begin{abstract}
The back story of twentieth-century art concerns the changing intellectual, economic, and technological setting that would cause the art of the past century to be fundamentally different from that of all earlier times. The single most important change involved the structure of the market for advanced art. Innovation had always been the hallmark of important art, but since the Renaissance nearly all artists were constrained in the degree to which they could innovate by the need to satisfy powerful individual patrons or institutions. The overthrow of the Salon monopoly of the art market in Paris and the rise of a competitive market for art in the late nineteenth century removed this constraint, and gave advanced artists an unprecedented freedom to innovate. Conspicuous innovation subsequently became necessary for important modern art. All artists recognized the increased demand for innovation, but it would be conceptual artists who could take advantage of it more quickly than their experimental counterparts. Early in the twentieth century Pablo Picasso became the prototype of the conceptual innovator who maximized the economic value of his inventiveness in the new market setting, and during the remainder of the century, a series of young conceptual artists followed him in producing more radical innovations, and engaging in more extreme new forms of behavior, than had ever existed before, making this an era of revolutionary artistic change.
\end{abstract}

\author{
David Galenson \\ Department of Economics \\ University of Chicago \\ 1126 East 59th Street \\ Chicago, IL 60637 \\ and NBER \\ galenson@uchicago.edu
}




\section{And Now for Something Completely Different}

WE DECLARE: ...

That the name of "madman" with which it is attempted to gag all innovators should be looked upon as a title of honor.

\section{Umberto Boccioni, Carlo Carra, Luigi Russolo, Giacomo Balla, and \\ Gino Severini, Futurist Painting: \\ Technical Manifesto, $1910^{1}$}

The title immortalized by Monty Python has three distinct meanings in the present context. Most generally, it is a remarkably apt description of the history of visual art in the twentieth century. Innovation has always been the distinguishing feature of important art, but the need for innovation to be conspicuous is a particular hallmark of the modern era, and the pace of change has accelerated within that era. So for example the critic Clement Greenberg observed in 1968 that "Until the middle of the last century innovation in Western art had not had to be startling or upsetting; since then... it has had to be that,” and just a year earlier, a critic of very different sensibility, Lucy Lippard, wrote that "Today movements are just that; they have no time to stagnate before they are replaced... Younger critics and artists have matured in a period accustomed to rapid change.”2 The twentieth century witnessed artistic changes that had no precedent in the history of our civilization, and it is now time to recognize the century as the Age of Something Completely Different.

The Monty Python effect also neatly characterizes a new model of artistic behavior that was invented early in the twentieth century, and went on to thrive over time. Fittingly, it was the century's greatest artist, Pablo Picasso, who first devised the practice of changing styles at will, and he was followed by a number of other key figures. The eminent critic David Sylvester observed that this was a kind of behavior that could not have existed before the twentieth 
century, for no artist who produced art in a variety of styles would have been taken seriously in an earlier time. That stylistic promiscuity was practiced by some of the greatest artists of the twentieth century clearly sets it apart from all earlier artistic eras. ${ }^{3}$

Finally, the Monty Python formula describes the nature of the present book. That this is true has come as a surprise to me. I began studying art history a decade ago, after doing research on economic and social history for nearly 25 years, as a member of both economics and history departments. It seemed natural to approach art history with the same blend of quantitative and qualitative techniques that I had learned and used in my earlier research. What surprised me, however, was the hostility I encountered from art historians, who almost unanimously refused to acknowledge the value that quantitative methods could have in their field, and who equally blindly refused to look past these methods to my conclusions. Unlike in the other fields of history I had encountered in my earlier research - not only economic, but also social, demographic, and urban history - quantification has been almost totally absent from art history. On the one hand, this meant that there were questions I could study, and large bodies of evidence I could use, that had effectively not been touched by earlier scholars, and this produced enormous intellectual gains: I have learned fascinating things about modern art that art historians do not know. On the other hand, I had to recognize that I would be treated as a hostile interloper by art scholars, simply because my work didn't look like theirs. I persevered in spite of their unfortunate lack of intellectual curiosity, and it is therefore with some residual surprise that I can point out that the use of measurement and systematic generalization in a study of twentiethcentury art makes this study something completely different. 


\section{$\underline{\text { Making it New }}$}

What modern art means is that you have to keep finding new ways to express yourself, to express the problems, that there are no settled ways, no fixed approach. This is a painful situation, and modern art is about this painful situation of having no absolutely definite way of expressing yourself.

Louise Bourgeois, $1988^{4}$

It has long been recognized that innovation is the core value of modern art. In 1952, for example, the critic Harold Rosenberg could remark that "the only thing that counts for Modern Art is that a work shall be NEW." 5 The recognition of this association first arose roughly a century earlier. In 1855 Charles Baudelaire, the poet and critic who was one of the earliest prophets of modern art, observed that the growing acceptance of change in nineteenth-century society would inevitably have an impact on artists' practices. He reasoned that the widespread appreciation of the great economic benefits of technological change in industry would lead to a demand for visible progress in all spheres, including art. $^{6}$ In a celebrated essay published in 1863, “The Painter of Modern Life,” Baudelaire proposed no less than a new "rational and historical theory of beauty,” that explained why artistic change must occur. He posited that although beauty did have "an eternal, invariant element," it also had a "relative, circumstantial element," that represented the contemporary - "the age, its fashions, its morals, its emotions.” The ambitious painter could not simply study the art of the Old Masters, but also had to seek to represent "modernity,” which consisted of "the ephemeral, the fugitive, the contingent.” And artists must be concerned not only to choose new contemporary subjects, but to represent them with new techniques, for in the accelerated pace of modern life "there is a rapidity of movement which calls for an equal speed of execution from the artist.”7

Paris became a battleground for advanced art during the late nineteenth century, as artists 
and the critics who championed them debated the merits of a rapid succession of new movements, from Impressionism and its challengers onward. So for example the philosopher and critic Arthur Danto recently compared the Paris art world of the 1880s to the New York art world of the 1980s - "competitive, aggressive, swept by the demand that artists come up with something new or perish.” ${ }^{8}$ Yet throughout these debates, the artists who played the leading roles implicitly accepted Baudelaire's formulation of the two elements of beauty, recognizing that they must learn from the best art of the past, but that they also must add new developments of their own making. It was with both of these elements in mind, for example, that in 1905 the aged Paul Cézanne explained to a critic that "To my mind one does not put oneself in place of the past, one only adds a new link.”9 And as advanced art spread out from Paris into other European capitals, the need for progress was always clearly understood. Thus in Moscow in 1919, the logic of Kazimir Malevich's declaration of the value of new artistic methods and means echoed Baudelaire's argument about the origin of the demand for the new in modern art: "Life develops with new forms; a new art, medium and experience are necessary for every epoch. To strive towards the old classical art would be the same as for a modern economic state to strive towards the economy of ancient states." ${ }^{\prime 10}$

Valuing Innovation

Well, thank God, art tends to be less what critics write than what artists make.

Jasper Johns, $1959^{11}$

Important artists are innovators whose work changes the practices of their successors. The greater the changes, the greater the artist. It is those artists who have the greatest influence on their peers, and the artists of later generations, whose work hangs in major museums, becomes the subject of study by scholars, and sells for the highest prices. 
There is a persistent belief, not only among the general public but even among many art scholars, that artistic importance can be manufactured, deliberately and artificially, by powerful critics, dealers, or curators. In the short run, prominent critics and dealers can unquestionably gain considerable attention for an artist's work. Yet unless this attention is transformed into influence on other artists, it cannot give that artist an important place in art history. Thus in 1965 Harold Rosenberg, who was himself a leading critic, conceded that "Manipulated fame exists, of course, in the art world.” Yet he emphasized that this fame was fleeting: "The sum of it is that no dealer, curator, buyer, critic or any existing combination of these, can be depended upon to produce a reputation that is more than a momentary flurry.” Real power in the art world came from only one source: "the single most potent force in the art world is still, in the last analysis, the artist ... A painter with prestige among painters is bound to be discovered sooner or later by the tastes of those who determine when an artist deserves to be bought, hired, or chosen as one of the four or fourteen Americans currently entitled to museum fanfare.”12

In 1989 Sir Alan Bowness, the former director of the Tate Gallery, presented a more formal version of this argument in a lecture titled "The Conditions of Success: How the Modern Artist Rises to Fame." Bowness explained that, contrary to the general supposition that artistic success is arbitrary or due to chance, there are in fact specific conditions of success, which can be precisely described, so that “Artistic fame is predictable.” Bowness contended that there are four successive stages on the exceptional artist’s path to fame: “peer recognition, critical recognition, patronage by dealers and collectors, and finally public acclaim.” The key was the first stage, of peer recognition - “the young artist's equals, his exact artist contemporaries, and then the wider circle of practicing artists." Once artists gave a peer their respect, the other stages would invariably follow: "it is always the artists themselves who are first to recognize 
exceptional talent."13

Rosenberg and Bowness both spoke from substantial art world experience - one from years of writing critical assessments of art, the other from years of acquiring and exhibiting art for a great public museum. Thus for example in support of his contention that the artist was the key force in the art world, Rosenberg explained that "It is to him that dealers and collectors, curators and art department heads turn for recommendations. It is his judgments of his colleagues that reviewers listen in on before committing themselves in their columns." ${ }^{\text {"14 }}$ But long before either Rosenberg or Bowness wrote the words quoted here, it was an artist who identified the most important reason why it is artists who are the key judges of artistic success. In 1910 the English painter Walter Sickert, who moonlighted as a critic, explained to an ambivalent London art world that there could no longer be any question as to the importance of the French Impressionists. Sickert analyzed two specific contributions of the group, in composition and the use of color, that led to a clear conclusion: "They have changed the language of painting.” This definitively settled the question of their importance, because of a simple criterion: "Perhaps the importance that we must attach to the achievement of an artist or a group of artists may properly be measured by the answer to the following question: Have they so wrought that it will be impossible henceforth, for those who follow, ever again to act as if they had not existed?’15 Important artists are those whose work changes the practices of other artists.

Alan Bowness contended that there had been no major change during the modern era in the process he described, and he was correct with respect to its structure - the sequence in which the artist was first recognized by other artists, then by other members of in the art world, and finally by the public. Yet one important change did occur, involving the speed with which the process occurred, as over time a series of critics, dealers, and collectors learned from the 
successes - and failures - of their predecessors. Each time a modern artist became famous, from Monet, Cézanne, van Gogh, and Gauguin on, one element of the retrospective narratives of their careers that always gained considerable public attention was the early, extended neglect of their work. For all those involved in the art market, whether critics who sought fame by becoming early champions of great artists, or dealers and collectors who sought riches by becoming early agents or patrons, each such episode carried a powerful lesson about unexploited profit opportunities. As time went on, it became clear that advanced art was producing a steady stream of important innovators, each of whom was passing through the sequence of stages that Bowness described. As the awareness of this process spread, the search for new and unrecognized innovators intensified. In 1968 the poet John Ashbery, who also moonlighted as an art critic, remarked on the result: "Looking back only as far as the beginning of this century we see that the period of neglect for an avant-garde artist has shrunk for each generation. Picasso was painting mature masterpieces for at least ten years before he became known to even a handful of collectors. Pollock's incubation period was a little shorter. But since then the period has grown shorter each year so that it now seems to be something like a minute. It is no longer possible, or it seems no longer possible, for an important avant-garde artist to go unrecognized.”16

\section{Generation Gaps, Part 1}

People who were formerly considered revolutionaries have now turned out to be counter-revolutionaries: the same thing happens in art.

$$
\text { Kazimir Malevich, } 1920^{17}
$$

Significant artistic innovators are of course not simply initially unappreciated: they are vigorously attacked. Any innovative new art form necessarily involves the rejection of older values. For practitioners and admirers of those older values, this causes "a sense of loss, of 
sudden exile, of something willfully denied ... a feeling that one's accumulated culture or experience is hopelessly devalued." ${ }^{18}$ It is hardly surprising that those committed to established forms refuse to accept innovations that would make those forms obsolete, and thus cause a devaluation of their own knowledge and skills. This phenomenon is not unique to art, but in scholarship is known as Planck's principle, named for the physicist Max Planck, who observed that "a new scientific truth does not triumph by convincing its opponents and making them see the light, but rather because its opponents eventually die, and a new generation grows up that is familiar with it.”19

Examples of great artists who evolved from youthful revolutionaries into aging reactionaries are not difficult to find. In spite of the fact that some of the most important abstract painters were deeply influenced by his own innovation of Cubism, Pablo Picasso never accepted the validity of abstract art. ${ }^{20}$ Picasso’s companion Françoise Gilot reported a remarkable conversation between Picasso and Henri Matisse that occurred in the early 1950s, when the two great painters had both passed the age of 70. After looking at some catalogues that reproduced recent paintings by the American Abstract Expressionists, Picasso categorically rejected the work: “As far as these new painters are concerned, I think it is a mistake to let oneself go completely and lose oneself in the gesture. Giving oneself up entirely to the action of painting there's something in that which displeases me enormously.” His old rival and friend was more circumspect. Matisse contended that artists couldn't understand the innovations of their successors, and therefore couldn't judge them: “One is always unable to judge fairly what follows one’s own work.” He explained that “One can judge what has happened before [one’s own work] and what comes along at the same time. And even when a painter hasn't completely forgotten me I understand him a little bit, even though he goes beyond me. But when he gets to 
the point where he no longer makes any reference to what for me is painting, I can no longer understand him. I can’t judge him either. It's completely over my head.” Unmoved by Matisse's caution, Picasso dismissed it, together with Jackson Pollock's art, declaring: "I don't agree with you at all. And I don't care whether I'm in a good position to judge what comes after me. I'm against that sort of stuff.",21

Others in the art world, including great dealers, are subject to the same forces. Leo Castelli opened an art gallery in New York in 1957, and just a year later presented Jasper Johns' first one-man exhibition, which was an immediate sensation in the art world. Castelli became the leading art dealer of the 1960s and '70s, representing Johns, Robert Rauschenberg, the major Pop artists - notably Andy Warhol, Roy Lichtenstein, and Claes Oldenburg - and such younger stars as Frank Stella, Richard Serra, and Bruce Nauman. In an interview in 1994, Castelli recalled his dismay when the 1993 Whitney Biennial exhibition had forced him to recognize the impact of new developments that had been occurring in advanced art, with the increased use of new media, including video, and the prominence of younger German and Italian painters: “I had to accept the fact that the wonderful days of the era I had participated in, and in which I had played a substantial role, were over.” He initially could not accept the legitimacy of the newer art: "I felt that what had been there before, during the great era of the sixties, was unbeatable, and that nothing of that kind could succeed the heroic times that we had had here in New York.” On reflection, however, he realized that he had to accept the new art, so that he would not repeat the universal error of aging art experts: "There was a certain sadness that I felt about it, but well, with the Whitney show, I realized that I had to change my attitude, and not be rejecting - as people generally are, as you know. Someone like Kahnweiler, for instance, after Picasso and the Cubists felt that there was no good art anymore. I would say that there is a span, a relatively 
short span, in which somebody really lives seriously with a period of art and after that, all those people - whether it be dealers or art historians or museum directors - after that they don't see what's going on anymore. They reject whatever comes after that. I didn't want to be one of those.” In spite of this recognition, however, in 1994 the 87-year-old Castelli confessed that he could not find any artist under the age of 50 whom he could consider genuinely important: "So for me, Nauman was really the last groundbreaking artist.",22

Significant innovations inevitably impose losses on those who cherish the values the new innovations reject, but of course they also offer gains. The artistic innovators who are faced with attacks on their new methods understand this. So for example Kazimir Malevich remarked in 1919 that "People always demand that art be comprehensible, but they never demand of themselves that they adapt themselves to comprehension., ${ }^{23}$ When artists create significant new forms of art, they almost invariably see their innovations denounced by critics who are judging their new methods by the rules or conventions of earlier art, which the innovators have intentionally discarded. Thus in 1914 Wassily Kandinsky warned against critics who claimed to have found flaws in new art: "one should never trust a theoretician (art historian, critic, etc.) who asserts that he has discovered some objective mistake in a work." Kandinsky explained that, in ignorance of the purpose of the new work, the detractor was invariably applying outmoded criteria: "The only thing a theoretician is justified in asserting is that he does not yet know this or that method. If in praising or condemning a work theoreticians start from an analysis of already existing forms, they are most dangerously misleading.” Ideally, a critic would take care to understand the new methods of the innovative new work, then explain it to a wider audience: "he would try to feel how this or that form works internally, and then he would convey his total experience vividly to the public."24 
Yet the difficulty of understanding innovative new art has increased over the course of the modern era, because of the increasing prominence of highly conceptual art. Harold Rosenberg argued that a shift occurred with the innovation of Cubism, because it substituted intellectual for aesthetic values: “Cubism changed the relation of art to the public, and, in so doing, changed the nature of the art public itself. It excluded those who merely responded to pictures and replaced them with spectators who knew what made pictures important.”25 Understanding advanced art would subsequently be primarily intellectual rather than visual: “An advanced painting of this century inevitably gives rise in the spectator to a conflict between his eye and his mind; as Thomas Hess has pointed out, the fable of the emperor's new clothes is echoed at the birth of every modernist art movement. If work in a new mode is to be accepted, the eye/mind conflict must be resolved in favor of the mind; that is, of the language absorbed into the work."26 It is perhaps not surprising that Picasso had earlier defended Cubism in almost precisely these terms. Thus in 1923 he told his friend Marius de Zayas that "The fact that for a long time cubism has not been understood and that even today there are people who cannot see anything in it, means nothing. I do not read English, an English book is a blank book to me. This does not mean that the English language does not exist, and why should I blame anybody else but myself if I cannot understand what I know nothing about?”27

In part, the difficulty at issue here is simply that of assimilating innovative new art in a period of rapid change. Thus Kirk Varnedoe recently reflected that "Early modern society created - and we have inherited - that paradoxical thing: a tradition of radical innovation,” and much earlier, in 1855, Charles Baudelaire's sardonic sensibility had led him to ponder the bittersweet nature of indefinite progress, wondering "whether proceeding as it does by a stubborn negation of itself, it would not turn out to be a perpetually renewed form of suicide, and whether 
... it would not be like the scorpion which stings itself with its own terrible tail - progress, that eternal desideratum which is its own eternal despair!" ${ }^{28}$ Yet as the specific terms used by Rosenberg and Picasso suggest, there is something more at stake here, involving the particular qualities of the art in question. This can be highlighted through the introduction of the analytical framework that will provide the theoretical basis for this study as a whole.

\section{The Language of Analysis}

Does creation reside in the idea or in the action?

\section{Sir Alan Bowness ${ }^{29}$}

There are two very different types of artistic innovators. These two types are not distinguished by their importance, for both are prominently represented among the very greatest artists. They are distinguished instead by their very conception of art - the goals they have for their work - and by the methods they use to produce that work.

Experimental innovators are motivated by aesthetic criteria: their goal is to present visual perceptions. They are uncertain how to do this, so they proceed tentatively and incrementally. The imprecision of their goals means that experimental artist rarely believe they have succeeded, and their careers are consequently often dominated by the pursuit of a single objective. These artists repeat themselves, returning to the same motif many times, gradually changing their treatment of it in an experimental process of trial and error. Each work leads to the next, and none is intended to be definitive, so experimental painters rarely make preparatory sketches or other plans for a painting. They consider the production of a painting as a process of exploring, in which they want to discover the image in the course of working, and they typically believe 
that learning is more important than creating finished works. Experimental artists build their skills gradually, improving their work slowly over the course of their careers. Many are perfectionists, who are plagued by frustration at their inability to achieve what they can consider satisfactory results. Their innovations appear gradually over extended periods: they are rarely declared in any single work, but instead appear piecemeal in a large body of work.

In contrast, conceptual innovators want to express ideas or emotions. Their goals for individual works can usually be stated precisely, in advance, either as a desired image or as a specific process for the work's execution. As a result, they often plan their works carefully, with detailed preparatory sketches or other instructions. Their execution of their works is often systematic, since many think of it as merely recording an image that has already been fully conceived. Conceptual innovations appear suddenly, as the realization of a new idea immediately produces a result distinctly different not only form other artists' work, but also from the artist's own previous work. Because it is the idea that is the real contribution, conceptual innovations can usually be implemented immediately and completely, and therefore are often fully embodied in individual breakthrough works that can be clearly recognized as the first statement of the innovation.

The clarity of their goals allows conceptual artists to be satisfied that they have made specific works that achieve a particular goal. Unlike experimental artists, whose inability to achieve their goals can tie them to a single problem for decades, the conceptual artist's ability to consider a problem solved can free the artist to pursue new goals. Some conceptual artists have consequently made a series of independent innovations, each quite different from the others. Thus whereas over time an experimental artist usually produces many works that are closely related to each other, the career of the conceptual innovator is often marked by discontinuity. 


\section{$\underline{\text { Generation Gaps, Part } 2}$}

You're a killer of art, you're a killer of beauty, and you're even a killer of laughter. I can't bear your work!

$$
\text { Willem de Kooning to Andy Warhol, } 1969^{30}
$$

If Warhol expressed his age the way Pollock expressed his, there was more than an artistic change between them, there was a historical revolution.

$$
\text { Arthur Danto }^{31}
$$

As noted earlier, artistic innovations always create a sense of loss for those who are committed to the values they reject. But the intensity of the clashes new innovations create can be magnified when experimental values are rejected by young conceptual innovators. In the modern era, the shifts in values can be so abrupt and extreme that aging experimental artists may have trouble accepting that young conceptual innovators are in fact serious artists at all.

One such shift occurred in New York in the late 1950s, as a series of young conceptual artists successfully challenged the dominance of the experimental art of the Abstract Expressionists. The older artists, who had spent decades working to develop new forms of art that would make profound statements about beauty and truth, could not accept the ready-made images of the young artists, who appeared to have no respect for the art of the past. After seeing the paintings of targets and flags at Jasper Johns' first one-man show in 1958, Mark Rothko commented, "We worked for years to get rid of all that."32 When Robert Motherwell first saw Frank Stella's early paintings of parallel black lines a year later, he remarked, “It's very interesting, but it's not painting. "33 Motherwell considered Pop art to be unrelated to fine art: “It's not possible to have an allegiance to painting and to pop art at the same time... As for the pop artists whom I've met, their detachment from aesthetic problems is incomprehensible to me. It 
fills me with a sort of horror.”34 To Motherwell, the Pop artists could not be serious artists, for they had no interest in the masters of the past: “The pop artists couldn't care less about Picasso or Rembrandt." ${ }^{35}$ A fellow painter explained why Rothko was so depressed in the early 1960s: "the problem was not just being replaced, but what was replacing him.”36

The critic Calvin Tomkins observed that it was not difficult to understand the Abstract Expressionists' anger at the rise of Pop art: “They had struggled for many years in total obscurity, their achievements recognized only by one another ... The recognition that they had so recently and so arduously won was now being usurped, or so they believed, by a new generation of brash youngsters who had become 'artists overnight,' who had not earned anything the hard way, and whose most apparent common bond seemed to be mockery and rejection of all serious art, especially Abstract Expressionism. Pollock and de Kooning and Rothko and Newman had not repudiated Picasso, Mondrian, and Léger. They had worshiped the European masters, while striving heroically to go beyond them. Now, suddenly, heroism and high art were out of style.”37

The Abstract Expressionists were separated from their chronological successors not merely by differences of style, but by differences in their very conception of art. Experimental artists who had spent their entire careers, and lives, working toward vague and elusive aesthetic goals could not accept new forms of art that not only rejected their particular goals, but that rejected aesthetic criteria altogether. The inability of these older experimental artists to respect the conceptual art of the younger painters meant that they could not accept them as successors, because they could not consider their conception of art to be valid. Transitions like this one, when an experimental art is replaced by conceptual innovations, therefore produce conflicts even deeper than those that occur when one style replaces another: the conceptual revolution of the late 1950s and early '60s produced such a vast change in values that the very survival of painting 
as a fine art seemed in doubt to the older experimental artists.

\section{$\underline{\text { Age and Innovation }}$}

When we look at the late works of Titian or Rembrandt we cannot help feeling the pressure of a massive and rich experience which leaks out, as it were, through the ostensible image presented to us whatever it may be. There are artists, and perhaps Titian and Rembrandt are good examples, who seem to require a very long period of activity before this unconscious element finds its way completely through into the work of art. In other cases, particularly in artists whose gift lies in a lyrical direction, the exaltation and passion of youth transmits itself directly into everything they touch and then sometimes, when this flame dies down, their work becomes relatively cold and uninspired.

Roger Fry, $1933^{38}$

The distinction between experimental and conceptual innovators will provide a basis for understanding a succession of novel practices of artists in the twentieth century. A number of implications of this analysis will be considered in the course of surveying these practices. Yet one implication involves an issue that is so basic, and that has been so completely neglected by art scholars ever since it was raised by the eminent critic Roger Fry more than seven decades ago, that it is worth spelling it out before beginning the examination of twentieth-century art and artists.

The two types of innovators have very different life cycles of creativity. The long periods of trial and error often required for important experimental innovations means that they tend to occur late in an artist's career. In contrast, conceptual innovators are generally best early in their careers. Major conceptual innovations require the ability to see old problems in radically new ways, and this ability declines with experience, as artists become accustomed to thinking and working in particular ways. Some conceptual artists make a series of distinct innovations over the course of their careers, but the most important of these will normally be the earliest, when 
they are least constrained by habits of thought.

These differing patterns of creativity over the life cycle reflect the very different attitudes and processes that affect the creative ability of the two types of artists. Experimental innovators' approach to their art is dominated by uncertainty, concerning both methods and goals. This leads them to proceed cautiously, in the belief that progress can only occur slowly. In many cases they in fact progress so slowly that for long periods their progress is imperceptible not only to others, but to the artists themselves; even the greatest experimental innovators often suffer from doubt over whether they have accomplished anything at all. They stress the need for patience, with the gradual accumulation of knowledge over time, and they trust their own experience more than any other sources of knowledge. In time they acquire better judgment of their own work, as they develop a personal aesthetic that becomes a consistent basis for their art, and for the new departures that emerge in the course of their research.

Conceptual innovators have a very different understanding of creativity: they believe that discoveries can occur suddenly, in flashes of insight, and that they can arrive fully formed, in discrete leaps of comprehension. Conceptual innovators are typically precocious young practitioners who quickly assimilate the art of the past, then violate basic conventions of that art. They are iconoclasts, whose self-confidence and lack of respect for established practices allows them to discard those practices at will. Because conceptual innovators value pronounced change, in many cases their work may display no consistent aesthetic. The diminution of their creativity over time is a product of the increasing rigidity that tends to set in as specific habits of thought and assumptions about what constitute proper artistic practices and products become fixed in their minds.

Roger Fry spoke the words quoted at the beginning of this section in 1933, on the 
occasion of his inaugural lecture as Slade Professor of Fine Art at Cambridge University. After stating this proposition, he immediately conceded that "I fear a great deal of this must appear to you to be rather wildly speculative and hazardous.” The stated task of his lecture was to outline a systematic approach to art "where at all events the scientific attitude may be fostered and the sentimental attitude discouraged." 39 It might normally be expected that the bold hypotheses of an inaugural lecture would become the subject of a new professor's research agenda in the years that follow. Unfortunately, however, Fry was elected to the Slade Professorship at the end of his career rather than the beginning, and his death the next year prevented any effort to document his hypothesis. ${ }^{40}$ In the event, no other art historian took up the challenge to pursue Fry's hypothesis of the life cycles of artistic creativity. Yet now, more than seven decades later, systematic research has provided a firm empirical basis for Fry's remarkable generalization, and many of the gains from this research will be seen throughout the course of this study.

\section{Measuring Artistic Importance}

There is, it seems, a graph of creativity which can be plotted through an artist's career.

Sir Alan Bowness ${ }^{41}$

Wassily Kandinsky believed that the judgment of the artist was critical to the creation of art, and that true art could not be made mechanically, through the use of mathematical calculation or any other system. ${ }^{42}$ In an essay of 1936, he extended this position, claiming not only that measurement could not be used to make art, but that measurement equally could not be used to judge the quality of art: “There has never been a 'thermometer' for measuring the level of art, and there never will be one." 43 This meant, for example, that it was impossible to determine when in an artist's career he had done his best work: "in the case of generally and rightly acknowledged artists, some 'specialists' constantly rate their 'early' period far higher than their 
'later' works, while other 'experts' maintain the opposite. Thus, there exist not simply individual works, but whole 'periods,' made up in turn of numerous individual works, for which no one has yet devised any 'yardstick of quality’ either. ${ }^{\text {„4 }}$

Kandinsky did not deny the existence of quality in art. Two years later, in 1938, he in fact devoted an essay to the problem of judging artistic value. The discussion again dealt with the irrelevance of calculation in assessing artistic quality, and the consequent impossibility of creating scientific standards. Yet at the end of the essay he offered a specific criterion to those who sought standards of value: “Ask yourselves, if you like, whether the work of art has made you free of a world unknown to you before.”45

Kandinsky thus recognized that innovation was the key standard for artistic importance: he simply did not see how this could be identified systematically. Yet since he wrote, art historians have devoted vast amounts of study to identifying the most innovative artists, and analyzing their most innovative contributions. And many other art historians have devoted considerable effort to surveying the results of these many studies of individual artists, and weaving them into summary narratives of the history of art. The resulting texts almost always contain illustrations, chosen to illustrate the most innovative works of the most innovative artists. No one of these books can be considered definitive, because no single scholar's choices can be assumed to be superior to those of his or her peers, but pooling the evidence of the many currently available books can effectively provide a systematic survey of art scholars' opinions on which artists have been most innovative, and on when in their careers they were most creative. Many quantitative studies of this kind have now been carried out, and they have shown that the method is a very useful one. One reason for this is that contrary to Kandinsky's belief, there is very little disagreement among art experts over which artists, and which periods of those artists' 
careers, are most important. ${ }^{46}$

The development of this method has made it possible to use systematic generalization in the study of art history, by effectively surveying the opinions of large numbers of experts on the art historical issues at hand. This method will provide an empirical basis for many issues treated by the present study.

Approaching the Twentieth Century: The Market for Advanced Art

You see that an era of a new art is opening, you feel it coming.

Paul Cézanne to Charles Camoin, $1902^{47}$

During the late nineteenth century, momentous changes in both markets and technology set the stage for an unprecedented era of revolutionary change in art. As a consequence of these changes, in a number of respects, advanced artists in the twentieth century enjoyed dramatically greater creative freedom than their predecessors. The single most important cause of this was a fundamental change in the economic structure of the market for advanced art.

Although the story of the Impressionists’ challenge to the official Salon has long been a staple in narratives of art history, art scholars have never fully appreciated the significance of the changes it initiated. The problem is that art scholars have generally not understood the connection between markets and the production of art; they have typically considered art markets as if they involved only dealers and collectors, who buy and sell works that have been made by artists who are unaware of, and uninterested in, the transactions to which their works are subjected after they have produced them. This conception is wrong: it is not only bad economics, but also bad art history. In this instance, it has prevented art scholars from understanding how the changes that occurred in the market for advanced art in the late nineteenth century gave artists an 
almost unprecedented degree of freedom in producing their art.

Since the Renaissance, most artists had faced markets for their work that were dominated by powerful institutions or individuals. In Paris immediately prior to the emergence of modern painting, the market for fine art was dominated by the government. ${ }^{48}$ The central institution in the art world was the Salon, an annual or biennial exhibition that was operated by the official Academy of Fine Arts. A painter's work could not be widely reviewed by critics, or considered for purchase by important dealers or collectors, until the painter had proven himself by having his work admitted to the exhibition by the Salon's jury. The most important artists were those who were deemed worthy of prizes by the jury, or were elected by the jury to honorary positions. The Salon held an effective monopoly of the legitimate presentation of new art to the public throughout most of the nineteenth century: until the 1870s, no aspiring artist could have a successful career without the jury's acceptance of his work. The work of important artists was sold by private galleries, but only after those artists had effectively been certified as important by having their work exhibited at the Salon, and in general the most valuable paintings were those that had actually been displayed at the Salon. The control of the official Salon over artistic success was so great that the sociologist Pierre Bourdieu observed that under this regime "the artist is a high-level civil servant," who had a highly structured "career, a well-defined succession of honors ... by way of the hierarchy of awards given at the Salon exhibitions.”49 This situation began to change in 1874, when Claude Monet and a group of his friends organized an independent exhibition that included paintings by 29 artists. Although its initial impact was limited, and its full significance would not be recognized until considerably later, the first Impressionist group exhibition in 1874 began a new era, in which the reputations of advanced artists would no longer be created in the Salon, but instead in independent group 
exhibitions. The most important of these would be the eight Impressionist exhibitions held during 1874-86, and the Salon des Indépendants, which was held annually from 1884 on. Analytically, the critical change that the Impressionists initiated in 1874 was the elimination of the official Salon's monopoly of the ability to present fine art in a setting that critics and the public would accept as legitimate. The Salon would no longer determine whether an aspiring artist could have a successful professional career. Monet and his fellow Impressionists were the first nineteenth-century painters to become leaders in Paris' art world without having received medals or other honors from the official Salon, but after 1874 this became the rule, as none of the later artists whom we now consider important made their reputations through the Salon, in the traditional manner. In 1902, one of the Impressionists’ most important successors paid tribute to their achievement, as Paul Gauguin described their independent exhibitions as "one of the most influential efforts ever made in France, only a handful of men, with only one weapon, their talent, successfully doing battle against a fearsome power made up of Officialdom, the Press, and Money."50

The Impressionist exhibitions created the possibility of presenting new advanced art to the public outside the control of the official Salon. Yet a genuinely competitive market for advanced art did not immediately come into existence, because of the slow emergence of private galleries that were willing to sell the work of new artists. So for example Vincent van Gogh reported from Paris in 1887 that "Trade is slow here. The great dealers sell Millet, Delacroix, Corot, Daubigny, Dupré, a few other masters at exorbitant prices. They do little or nothing for young artists. The second class dealers contrariwise sell these at very low prices. ${ }^{~ 51}$ Four of the artists van Gogh mentioned by name were dead, while the fifth, Dupré, was 76 years old, and all five had established their reputations at the official Salon. A few dealers became known for 
selling the work of younger artists - Paul Durand- Ruel, for example, began buying paintings from Monet and the other Impressionists in the early 1870s, and Ambroise Vollard sold paintings by Cézanne, Gauguin and others in the 1890s - but there were not enough of these dealers to create real competition for these artists' work. The underlying problem was that there were few collectors who would consistently buy the work of new advanced artists during the late nineteenth century. $^{52}$

In the early years of the twentieth century, the number of independent entrepreneurial art dealers who were willing to exhibit the work of younger artists who had not achieved success at the Salon began to grow, as the improving market for the work of the Impressionists and the leading Post-Impressionists demonstrated the potential profitability of innovative contemporary art. $^{53}$ This opened the way for another important transition in the market for advanced art. Although group exhibitions continued to proliferate, and a growing number of independent societies sponsored salons that might display thousands of paintings, private galleries became increasingly important in presenting new art to the public. Thus for example by 1910 the leading critic of the advanced art world, the poet Guillaume Apollinaire, observed that "The plethora of individual exhibitions tends to weaken the effect of the large annual salons. The curiosity of the public is less keen, since many painters have already shown in the galleries the most important, if not the best, examples of their work during the year."54 Over time, private galleries would replace group exhibitions altogether as the key exhibition spaces for new advanced art, and this would remain true not only in Paris, but also in other art centers, for the balance of the twentieth century. Interestingly Pablo Picasso, who first arrived in Paris from his native Spain in 1900, would become the first important modern artist who established himself by exhibiting exclusively in private galleries rather than large group exhibitions. In this he set an example that 
would be followed by nearly every important artist for the remainder of the twentieth century.

The Impressionists thus set in motion the process that eventually transformed the market for fine art from a monopoly, to which artists' entry was controlled by the French government and its institutions, into a highly competitive market. Unlike most of their predecessors since the Renaissance, advanced artists of the twentieth century would rarely produce commissions for wealthy and powerful patrons, and would rarely if ever be in the position of having to produce works that were subject to the approval of any official judge or jury. The elimination of official gatekeepers has meant that artists of the past century have had greater freedom to work, and to innovate, as they have pleased. The only constraint on their ability to do this has been that discussed earlier, namely the lag in recognition of important new art by critics, dealers, and collectors. And here too there is a relevant process that originated in the nineteenth century and has continued over time, namely the growing awareness in the art world that early investments in the work of innovative artists can yield handsome financial returns. The collectors who have captured these returns have most often done so as a result of advice from artists, who are the first to recognize other talented artists. The growing recognition that innovative art will increase in value consequently produced a result that has sustained the early careers of many innovative artists, as Alan Bowness observed that "Almost every major talent attracts one or two collectors at an early stage in his career, and these collectors almost always appear on the scene because of their friendships with artists, whose advice they take. ${ }^{, 55}$ This is a key feature of the existence of a competitive art market: innovative artists do not have to make work that appeals to the public at large, or even to large numbers of collectors, but need simply find one or two consistent purchasers of their work among the hundreds, or thousands, who see their work in exhibitions. If these few collectors support the innovator long enough for his influence on other artists to 
become apparent, many other collectors will invariably discover their own admiration for the artist's work.

An early landmark in the demonstration of the investment value of innovative contemporary art occurred in 1914, at an auction in Paris. Ten years earlier, a young businessman named André Level had organized a consortium of collectors, as he and 12 other partners each contributed to a collective fund that allowed Level to spend 2,750 francs a year on art. The group was named La Peau de l'Ours (the Bear Skin), after a La Fontaine fable in which two trappers sold a furrier the skin of a great bear before they had tried - and failed - to catch it. Level bought paintings by earlier artists, including Gauguin and van Gogh, but invested most heavily in the work of younger artists, particularly Matisse and Picasso. When the accumulated paintings were sold at the end of 10 years, the auction realized 116,545 francs, or more than four times the group’s total investment. Paintings by Matisse and Picasso brought the highest prices, and a major early work by Picasso, The Family of Saltimbanques (now in the National Gallery in Washington) sold for 12,650 francs, more than twelve times the price Level had paid for it in 1905. The auction's results were seen as a great success for Fauvism and Cubism, and news reports of this victory spread the fame of Picasso and Matisse not only throughout France, but also abroad, including the United States. The Peau de l'Ours sale was the first time an important group of works by the leading artists of the day had come to auction, and its public success helped to convince many people that contemporary innovative art could be a good investment. ${ }^{56}$ This laid the foundation for a new era of artistic freedom, that allowed artists to follow their own interests rather than those of patrons.

\section{Approaching the Twentieth Century: Photography}

From today painting is dead. 
French painter Paul Delaroche, upon learning of the invention of the daguerrotype, $1839^{57}$

The camera cannot compete with brush and palette - as long as it cannot be used in Heaven or Hell.

Edvard Munch, $1904^{58}$

Technological changes also had an important impact on the course of modern art. Most notably, the improvement of photography from the 1840s on affected painters in a number of ways.

By the early twentieth century, conceptual painters could use the availability of photography as an argument for a new division of labor. So for example in an interview in 1909, Matisse contended that it was time for painting to break decisively with the realistic goals of Impressionism. He declared that it was no longer necessary for painting to be concerned with objectivity, because this could be provided by photography: “The painter no longer has to preoccupy himself with details. The photograph is there to render the multitude of details a hundred times better and more quickly.” The painter was now free to pursue expression: "Plastic form will present emotion as directly as possible and by the simplest means." ${ }^{\text {59 }}$ Nor is it surprising that Picasso agreed. In 1939, while looking at photographs of Parisian street life taken by his friend Brassaï, Picasso remarked that "When one sees what you express through photography, one realizes everything that can no longer be the concern of painting. Why would the artist stubbornly persist in rendering what the lens can capture so well? That would be crazy, don't you think? Photography came along at a particular moment to liberate painting from literature of all sorts, from the anecdote, and even from the subject. In any case, a certain aspect of the subject now belongs to the realm of photography. Shouldn't painters take advantage of 
their new-found freedom, and do something else?"60

Yet photography also directly complemented the artistic practice of Matisse and Picasso, and other later conceptual artists, in several important ways. One of these was to stand in for a model. Conceptual painters generally plan the images in their works, and one way to do this is through the use of photographs. So for example John Richardson noted that Picasso’s 1908 portrait of Clovis Sagot was based on a photograph Picasso took of the dealer, "a practice he would resort to ever more frequently."61 Matisse had begun using the same practice, basing sculptures as well as paintings on photographs, a few years earlier. ${ }^{62}$ Over the course of the twentieth century, photographs would become increasingly important for the work of many conceptual painters.

Another conceptual function of photography was to provide a convenient access to the history of art. Conceptual artists typically innovate by creating syntheses of specific elements drawn from earlier art: Picasso is again a prime example. Thus his early masterpiece, Les Demoiselles d'Avignon, contains references to, or quotations from, the paintings of Cézanne and Gauguin, Egyptian and pre-Roman Iberian sculpture, and African carvings. ${ }^{63}$ This art was available to him not only in Paris’ museums, but even more conveniently in photographs. Thus William Rubin observed that "The growth of museums since the early nineteenth century and, even more, the documentary use of photography have made available a world of images that earlier artists could never have seen... This simultaneous accessibility of all historical sources, which sets the modern period off from any other, is encapsulated in the oeuvre of Picasso.”64 Throughout the twentieth century, conceptual artists could draw on the entire history of art without having to travel, or even go to their local museums, through the medium of photography, and this availability would have a major impact on the appearance of fine art. 


\section{The Growing Audience for Art}

Art's popular. That's my generation. It wasn't before.

$$
\text { Damien Hirst, } 2000^{65}
$$

A few changes in the environment of advanced art that occurred during the twentieth century are so central to an appreciation of the context of the century's art history that they demand at least brief preliminary mention. One is a very substantial increase over the course of the century in public interest in art in general, and in modern art in particular.

An obvious manifestation of this trend is the growing importance of museums. A milestone early in the twentieth century was the opening of New York's Museum of Modern Art in 1929. Not only was it the first American museum dedicated to modern art, but it defined its mission broadly, to include collections and displays devoted to photography, architecture, film, and design, as well as painting and sculpture. ${ }^{66}$

Attendance at museums became a topic of increasing economic importance after midcentury, as greater prosperity and rising levels of tourism contributed to steady increases in the volume of museum visits, with an accelerating rate of increase in the final decades of the century. ${ }^{67}$ A key contribution to this trend was made by Thomas Hoving, who served as director of New York's Metropolitan Museum during 1967-77. Hoving envisioned museums as places of mass entertainment, and he is considered the originator of the blockbuster exhibition, aimed at attracting both large public audiences, who often pay substantial admission fees, and lucrative corporate sponsorships. ${ }^{68}$ As attendance rose, and museums competed more actively for the public's patronage, many museums established marketing departments for the first time. ${ }^{69}$

Growing attendance at existing museums was complemented by the establishment of new museums, and many of these focused on modern art. One important instance occurred in 1977, 
when the opening of the Centre Pompidou gave Paris a major museum devoted exclusively to twentieth-century art. In 2000, Tate Modern gave London its first major museum of the art of the century just completed. Tate Modern quickly became the world's most popular museum of modern art, as for example during 2007 more than 5 million people visited the museum.

Another new museum that immediately became a major attraction to tourists when it opened in 1997 was the Guggenheim Museum in Bilbao, in northern Spain. Designed by Frank Gehry, the Guggenheim Bilbao has widely been recognized as the most important new museum architecturally since the New York Guggenheim, designed by Frank Lloyd Wright, opened in 1959. The spectacular Guggenheim Bilbao was the most successful to date of a series of satellite institutions created and planned by the New York-based Guggenheim in an attempt to become the first global museum. ${ }^{70}$

As museums multiplied and expanded, their attention to recent art increased: many small museums of contemporary art were opened, and larger museums of modern art began to devote significant amounts of space to the work of living artists. One notable manifestation of this new interest was the Turner Prize, established by London's Tate Gallery in 1984 with the intention of giving contemporary English visual art a status comparable to that afforded English novels by the Booker Prize. From 1991, the Turner Prize was restricted to artists under the age of 50, and the focus on younger artists increased the attention given to the prize. Attendance at the Tate's Turner Prize exhibition rose sharply during the '90s, and media attention expanded accordingly; heated controversies now regularly erupt over the nominees and winners of the prize, not only in broadsheet newspapers, but equally in the English tabloids. ${ }^{71}$

\section{$\underline{\text { Artists as Celebrities }}$}

Picasso is now wealthier and more famous than any other artist 
who has ever lived.

John Berger, $1965^{72}$

With the growing public interest in modern art came a new public status for important modern artists. Since the Renaissance, gifted artists had often been accorded great respect by their patrons. So for example in 1506 the pope was willing "to forgo his claims to reverential submission from an artist whose genius he fully appreciated," as Julius II "met Michelangelo as an equal” in order to gain the artist's agreement to paint the ceiling of the Sistine Chapel. ${ }^{73}$ Similarly, in the seventeenth century Philip IV of Spain granted Velázquez honors normally reserved for men of noble descent, and was devastated by the painter's death. ${ }^{74}$ In 1667 , when the young Prince Cosimo, the future Archduke of Tuscany, traveled to Amsterdam, one of the artists whose studio he visited was described in the official logbook of his journey as "Rembrandt the famous painter." ${ }^{75}$

These and other master painters were honored by kings, popes, and aristocrats. Yet it was only in the modern era that living artists would gain fame among a much wider public. As the audience for art expanded during the modern period, some artists became genuine celebrities. New forms of artistic behavior became possible as these artists responded to the opportunities their new status presented. Many of these behaviors will be examined in the course of this study. Here it is useful to point out a few of the most prominent cases of twentieth-century artists as celebrities.

A biographer remarked that Pablo Picasso "mastered the publicity game before the world knew that such a game existed. ${ }^{76}$ Early in his career Picasso created not only a startlingly new style of art, but also cultivated a colorful persona to match it. Thus one art scholar observed that by 1914, "Picasso had established the character of his genius: an amalgam of alchemist, 
Shakespearean fool, and satyr that placed his creative imagination at the center of his art." ${ }^{\text {"7 }}$ His Cubist fragmentation of the human figure, which could readily be caricatured by cartoonists, and his many love affairs combined to make Picasso "the archetypal modern artist as far as lay people were concerned." ${ }^{78}$ Considerable mystery surrounded Picasso, for he rarely granted interviews, but he nonetheless played an active role in fostering the spread of his fame through the press. So for example in 1939, photographs of Picasso taken by his friend Brassaï were featured in Life magazine. It was a time of considerable stress for the artist, for Picasso was busy moving his accumulated paintings and drawings into bank vaults to protect them from possible German bombing of Paris. Yet Brassaï noted that for the Life assignment, "Nonetheless, he was prepared to devote an entire day to me."79

Jackson Pollock became the prototype of the American artist as celebrity: an art historian observed that "while his career peaked before modern media saturation was achieved, he was the first modern artist to be given wide publicity in the popular press even before his avant-garde reputation had been secured."80 Pollock's fame was established in 1949, when Life magazine published a story titled "Jackson Pollock: Is He the Greatest Living Painter in the United States?," which described him as "the shining new phenomenon of American art," and "a fine candidate to become 'the greatest American painter of the $20^{\text {th }}$ Century.'”81 During the next few years Pollock's public image was enhanced by Hans Namuth's photographs of him working: the black-and-white pictures, often blurred as Pollock danced around, stepped on, or knelt beside large canvases laid flat on the floor, a cigarette dangling from his mouth as he spattered or smeared paint with sticks, gave vivid meaning to the term "action painting" that the critic Harold Rosenberg had devised to refer to Abstract Expressionism. Early in 1956, just months before his 
premature death in an automobile accident, Time magazine gave Pollock his lasting nickname, "Jack the Dripper," in a reference to his trademark technique of applying paint. ${ }^{82}$

Robert Hughes observed that Andy Warhol was "the first American artist to whose career publicity was truly intrinsic.." ${ }^{83}$ Warhol not only actively courted fame, but made celebrity itself a theme of his art. ${ }^{84}$ Neal Gabler contended that "What Warhol realized and what he promoted in both his work and his life ... was that the most important art movement of the twentieth century ... was celebrity. Eventually, no matter who the artist was and no matter what school he belonged to, the entertainment society made his fame his achievement and not his achievement his fame." ${ }^{85}$ As early as 1964, Newsweek titled a profile of Warhol "Saint Andrew," and in 1970, Vogue declared that "Andy Warhol is the most famous artist in America. For millions, Warhol is the artist personified. ${ }^{, 86}$ Warhol not only produced vast numbers of art works at a studio he named "The Factory," but he also managed a famous rock band, the Velvet Underground, he directed movies that some critics considered important innovations, and he published Interview, a magazine in which celebrities were interviewed, often by other celebrities. Warhol survived being shot by a disturbed member of his sizeable entourage, but he later died after a routine operation. After Warhol's death in 1989, the critic Arthur Danto surveyed his career, and predicted that "When the final multivolume Popular History of Art is published, ours will be the Age of Warhol - an unlikely giant, but a giant nonetheless.”87

Damien Hirst may be the most famous artist working today. He freely admits that this was always his plan: "I wanted to be a famous artist.” Fame allows him to achieve his real goal: "As an artist, you have a desire to communicate an idea to a hell of a lot of people on a massive scale. ${ }^{\prime 88}$ From an early stage of his career, Hirst combined dramatic art works, including some that presented dead animals preserved in formaldehyde in large vitrines, with a public persona 
borrowed from British punk rockers, that has been described as an "art yobbo" image: "Hirst glared, grimaced and grinned at the camera and cultivated a puckish image by not shaving,

wearing long or very short hair and a weird assortment of clothes along with oversize boots.”æ9

The success of his campaign was such that the critic Jerry Saltz has observed that he is "the one true pop-star artist.” Interestingly, however, Hirst's success is due in part to his art's studious conceptual synthesis of many important strands of contemporary art: "His art is an original mélange, a mutant sprung from virtually every movement that preceded it." ${ }^{\text {90 }}$ Through his entrepreneurship, his flamboyant art, and his colorful personal image, Hirst has become not only the leader but also the symbol of the young British artists, or yBas, who made London a center of the art world in the 1990s: "He’s their prophet and deliverer, their Elvis and ayatollah.” And he achieved this through a flair for arousing controversy that even Warhol would have admired: "To his supporters, Hirst is an inspiration and lightning rod; to his critics, he's a black sheep and bad egg. ${ }^{91}$

Thirteen Ways of Looking at Modern Art

The aim of the historian... is to portray time... He transposes, reduces, composes, and colors a facsimile, like a painter, who in his search for the identity of the subject, must discover a patterned set of properties that will elicit recognition all while conveying a new perception of the subject.

George Kubler $^{92}$

The necessary preliminaries are now complete. The remainder of this book will be devoted to an analytical history of art in the twentieth century. The next four chapters will give a quantitative overview of the most important figures in that history, and their achievements. The balance of the book will deal with a series of selected topics, chosen to represent key innovations in the work and behavior of artists in the twentieth century. The goal of this study as a whole is 
to examine systematically many old problems, and some new ones, from novel points of view, and in the process to discover patterns that will give both experts and nonspecialists a new perception of twentieth-century art, and an understanding of why it is fundamentally different from the art of all earlier times. 
$\underline{\text { Footnotes }}$

I thank Robert Jensen for discussions.

1. $\quad$ Umbro Apollonio, ed., Futurist Manifestos (New York: Viking Press, 1973), p. 30.

2. Clement Greenberg, The Collected Essays and Criticism Vol. 4 (Chicago: University of Chicago Press, 1993), p. 300; Lucy Lippard, Changing (New York: E. P. Dutton, 1971), pp. 27-31.

3. David W. Galenson, “And Now for Something Completely Different: The Versatility of Conceptual Innovators,” Historical Methods, Vol. 40, No. 1 (2007), pp. 17-27.

4. Louise Bourgeois, Destruction of the Father, Reconstruction of the Father (Cambridge: MIT Press, 1998), p. 166.

5. Harold Rosenberg, The Tradition of the New (New York: Da Capo Press, 1994), p. 37.

6. Charles Baudelaire, Art in Paris, 1845-1862 (London: Phaidon Press, 1965), p. 126.

7. Charles Baudelaire, The Painter of Modern Life and Other Essays (New York: Da Capo Press, 1986), pp. 3-4, 13.

8. Arthur Danto, Embodied Meanings (New York: Farrar, Straus and Giroux, 1994), p. 85.

9. $\quad$ Paul Cézanne, Letters (New York: Da Capo Press, 1995), p. 313.

10. K. S. Malevich, Essays on Art, 1915-1933, Vol. 1 (London: Rapp and Whiting, 1969), p. 89.

11. Jasper Johns, Writings, Sketchbook Notes, Interviews (New York: Museum of Modern Art, 1996), p. 19.

12. Harold Rosenberg, Discovering the Present (Chicago: University of Chicago Press, 1973), pp. 111-18.

13. Alan Bowness, The Conditions of Success (New York: Thames and Hudson, 1990), pp. 7, 11, 16.

14. Rosenberg, Discovering the Present, p. 118.

15. Walter Sickert, The Complete Writings on Art (Oxford: Oxford University Press, 2000), p. 253.

16. John Ashbery, Reported Sightings (New York: Alfred A. Knopf, 1989), p. 392. 
17. Malevich, Essays on Art, vol. 1, p. 170.

18. Leo Steinberg, Other Criteria (London: Oxford University Press, 1972), p. 7.

19. Max Planck, Scientific Autobiography and Other Papers (New York: Greenwood Press, 1968), pp. 33-34.

20. Alfred Barr, Picasso (New York: Museum of Modern Art, 1946), p. 273; Roland Penrose, Picasso third ed. (Berkeley: University of California Press, 1981), p. 159.

21. Francoise Gilot and Carlton Lake, Life With Picasso (New York: Anchor Books, 1989), pp. 268-70.

22. Suzi Gablik, Conversations Before the End of Time (New York: Thames and Hudson, 1995), pp. 459-61, 464.

23. Malevich, Essays on Art, Vol. 1, p. 95.

24. Wassily Kandinsky and Franz Marc, eds., The "Blaue Reiter” Almanac (NY: Viking Press, 1974), pp. 170-72

25. Harold Rosenberg, Art on the Edge (Chicago: University of Chicago Press, 1983), p. 162.

26. Harold Rosenberg, The De-Definition of Art (Chicago: University of Chicago Press, 1983), p. 56.

27. Barr, Picasso, p. 270.

28. Kirk Varnedoe, Pictures of Nothing (Princeton: Princeton University Press, 2006), p. 41; Baudelaire, Art in Paris, p. 127.

29. Alan Bowness, Modern European Art (New York: Thames and Hudson, 1995), p. 73.

30. Victor Bockris, Warhol (NY: Da Capo Press, 1997), p. 320.

31. Arthur Danto, Beyond the Brillo Box (Berkeley: University of California Press, 1992), p. 46.

32. James Breslin, Mark Rothko (Chicago: University of Chicago Press, 1993), p. 427.

33. Thierry de Duve, Kant after Duchamp (Cambridge: MIT Press, 1996), p. 216.

34. Dore Ashton, ed., The Writings of Robert Motherwell (Berkeley: University of California Press, 2007), p. 239. 
35. Stephanie Terenzio, ed., The Collected Writings of Robert Motherwell (New York: Oxford University Press, 1992), p. 137.

36. Breslin, Marko Rothko, p. 433.

37. Calvin Tomkins, Odd the Wall (Harmondsworth: Penguin, 1981), p. 185.

38. Roger Fry, Last Lectures (Boston: Beacon Press, 1962), pp. 14-15.

39. Fry, Last Lecture, pp. 3, 15.

40. Virginia Woolf, Roger Fry: A Biography (San Diego: Harcourt Brace Jovanovich, 1976), pp. 286-87.

41. Bowness, The Conditions of Success, p. 51.

42. Wassily Kandinsky, Complete Writings on Art (New York: Da Capo Press, 1994), pp. 769-70.

43. Kandinsky, Complete Writings on Art, p. 787.

44. Kandinsky, Complete Writings on Art, p. 786.

45. Kandinsky, Complete Writings on Art, p. 828.

46. E.g. see David Galenson, Artistic Capital (London: Routledge, 2006).

47. Cézanne, Letters, p. 281.

48. For elaboration of the argument presented in this and the following paragraph, see David Galenson and Robert Jensen, "Careers and Canvases: The Rise of the Market for Modern Art in the Nineteenth Century," Van Gogh Studies, Vol. 1 (2007), pp. 137-66.

49. Pierre Bourdieu, The Field of Cultural Production (New York: Columbia University Press, 1993), pp. 242-43.

50. Paul Gauguin, The Writings of a Savage (New York: Da Capo Press, 1996), p. 225.

51. Vincent van Gogh, The Complete Letters of Vincent van Gogh, second ed., Vol. 2 (Greenwich, Ct.: New York Graphic Society, 1959), p. 515.

52. $\quad$ E.g. see Camille Pissarro, Letters to His Son Lucien (New York: Da Capo Press, 1995), pp. 162-63, 174.

53. Michael Fitzgerald, Making Modernism (Berkeley: University of California Press, 1996), 
Chapter 1.

54. Guillaume Apollinaire, Apollinaire on Art (Boston: MFA Publications, 2001), p. 75.

55. Bowness, The Conditions of Success, p. 39.

56. John Richardson, A Life of Picasso, Vol. 2 (New York: Random House, 1996), pp. 29798; Fitzgerald, Making Modernism, Chapter 1.

57. Arthur Danto, After the End of Art (Princeton: Princeton University Press, 1997), pp. 75, 137.

58. Arne Eggum, Munch and Photography (New Haven: Yale University Press, 1989), p. 6.

59. Jack Flam, Matisse on Art (Berkeley: University of California Press, 1995), p. 54.

60. Brassaï, Conversations with Picasso (Chicago: University of Chicago Press, 1999), p. 55.

61. $\quad$ Richardson, A Life of Picasso, Vol 2, p. 108.

62. Jack Flam, Matisse (Ithaca: Cornell University Press, 1986), pp. 183, 197, 269, 315.

63. George Heard Hamilton, Painting and Sculpture in Europe, 1880-1940 (Harmondsworth: Penguin, 1972), p. 237.

64. William Rubin, "Primitivism" in 20 $0^{\text {th }}$ Century Art, Vol. 1 (New York: Museum of Modern Art, 1984), p. 10.

65. Damien Hirst and Gordon Burn, On the Way to Work (New York: Universe Publishing, 2002), p. 169.

66. Russell Lynes, Good Old Modern (New York: Atheneum, 1973).

67. James Heilbrun and Charles Gray, The Economics of Art and Culture, second ed. (Cambridge: Cambridge University Press, 2001), p. 191.

68. Karsten Schubert, The Curator's Egg (London: One-Off Press, 2000), pp. 72-79; Karl Meyer, The Art Museum (New York: William Morrow and Company, 1974), pp. 106-17.

69. Schubert, The Curator's Egg, pp. 70-71.

70. Schubert, The Curator's Egg, Chap. 6.

71. Virginia Button, The Turner Prize: Twenty Years (London: Tate Gallery, 2003). 
72. John Berger, The Success and Failure of Picasso (New York: Vintage Books, 1993), p. 3.

73. Margot and Rudolf Wittkower, Born Under Saturn (New York: New York Review Books, 2006), p. 40.

74. Wittkower, Born Under Saturn , p. 278.

75. Ernst van de Wetering, Rembrandt (Berkeley: University of California Press, 2000), pp. 265-66.

76. John Walker, Art and Celebrity (London: Pluto Press, 2003), p. 197.

77. David Cottington, Modern Art (Oxford: Oxford University Press, 2005), p. 74.

78. Walker, Art and Celebrity, p. 197.

79. Brassï, Conversations with Picasso, p. 50.

80. Cottington, Modern Art, p. 90.

81. Pepe Karmel, ed., Jackson Pollock (New York: Museum of Modern Art, 1999), p. 63.

82. B. H. Friedman, Jackson Pollock (New York: Da Capo Press, 1995), p. 213.

83. Alan Pratt, ed., The Critical Response to Andy Warhol (Westport, Ct: Greenwood Press, 1997), p. 149.

84. Cottington, Modern Art, p. 91.

85. Neal Gabler, Life the Movie (New York: Alfred A. Knopf, 1998), p. 135.

86. Pratt, The Critical Response to Andy Warhol, pp. 8, 60.

87. $\quad$ Pratt, The Critical Response to Andy Warhol, p. 207.

88. Hirst and Burn, On the Way to Work, pp. 86, 72.

89. Walker, Art and Celebrity, p. 244.

90. Jerry Saltz, Seeing Out Loud (Great Barrington, MA: The Figures, 2003), pp. 218-19.

91. Saltz, Seeing Out Loud , p. 220.

92. George Kubler, The Shape of Time (New Haven: Yale University Press, 1962), p. 12. 